Vol4. No 1. Februari 2020

ISSN 2580-5029

\title{
Studi Populasi Ikan Beloso (Oxyurichthys microlepis) di Perairan Morosari Kec. Sayung, Demak
}

\author{
Dian Sari Maisaroh'1, Sri Rejeki ${ }^{2}$ dan Muhammad Zainuri ${ }^{2}$ \\ ${ }^{1}$ Marine Science Program, Science and Technology of Faculty, UIN Sunan Ampel, Surabaya, \\ Indonesia \\ ${ }^{2}$ Marine Science Department, Fisheries and Marine Science of Faculty, Diponegoro University, \\ Semarang, Indonesia \\ *maisaroh.ds@uinsby.ac.id
}

\begin{abstract}
This study aims to study population of beloso fish. The research was conducted between May-June 2010 at Morosari Waters Area, District SayungDemak. Beloso fish catches are measured standard length, total length and weight. The data analysis suchgrowth was using Von Bertalanffy, length weight relationship, conditional factor and, food and feeding habits.Growthof beloso fish $(O$. microlepis) in Morosari waters area has a value of $L \infty$ of $13,49 \mathrm{~cm}$ by the equation $L(t)=13,49$ ( 1 - exp 0,0175 (t-1,9053)) for length, while based on the weight obtained for $W \infty 128,33$ grams with the equation $W(t)=128,33\left(1-\exp ^{-0,003(t-2,4312)}\right)^{3}$. Length-weight relationship beloso fish have value of b1,451 in the Morosari waters area. This value indicates that the growth of beloso fish is negative allometric, which the addition of lengthis faster than its weight. Based on data calculations of beloso fish condition factor in the Morosari waters shows the range of condition factors from 0,0965 to 0,3661, which are preferred food energy accretion term. Beloso fish areomnivorous fish that consume phytoplankton, zooplankton, and detritus as food found in the Morosari estuary.
\end{abstract}

Keywords: Population, length-weight relationship, condition factor, beloso fish

\begin{abstract}
ABSTRAK
Penelitian ini bertujuan untuk mengetahui populasi ikan beloso. Penelitian dilaksanakan pada bulan Mei - Juli di Perairan Morosari, Kec. Sayung, Kab. Demak. Metode penelitian adalah eksploratif deskriptif, sedangkan pemilihan lokasi didasarkan kepada purposive sampling method, dimana lokasi penelitian dipilih berdasarkan pertimbangan tertentu. Ikan beloso ditangkap dengan menggunakan lift net. Ikan beloso hasil tangkapan diukur panjang standar, panjang total dan berat. Data yang diperoleh dianalisis dengan menggunakan model pertumbuhan Von Bertalanffy, hubungan panjang-berat, faktor kondisi dan kebiasaan makan ikan.Pertumbuhan ikan beloso (O. microlepis) di Perairan Morosari memiliki nilai L $\infty$ sebesar $13,49 \mathrm{~cm}$ dengan persamaan $\mathrm{L}(\mathrm{t})=13,49$ ( $1-\exp { }^{0,0175}(\mathrm{t}-1,19053)$ ) untuk panjang, sedangkan berdasarkan berat diperoleh $W \infty$ sebesar 128,33 gram dengan persamaan $W(t)=128,33$ ( 1 exp -0,003 (t-2,4312) $)^{3}$. Hubungan panjang-berat ikan beloso di Perairan Morosari menghasilkan nilai b sebesar 1,451. Nilai ini menunjukkan bahwa pertumbuhan ikan beloso bersifat allometrik negatif, dimana pertambahan panjang lebih cepat dari beratnya. Berdasarkan hasil perhitungan data faktor kondisi ikan beloso di Perairan Morosari menunjukkan kisaran faktor kondisi sebesar 0,0965 - 0,3661, dimana energi makanan lebih diutamakan pertambahan panjang. ikan beloso merupakan ikan omnivora yang mengkonsumsi fitoplankton, zooplankton, dan detritus sebagai makanan yang dijumpai di daerah estuari Perairan Morosari.
\end{abstract}

Kata Kunci: Populasi, hubungan panjang-berat, faktorkondisi, ikan beloso 


\section{PENDAHULUAN}

Perairan Morosari yang terletak di Desa Morosari, Kecamatan Sayung Kabupaten Demak ini merupakan perairan estuaria. Perairan tersebut sangat dipengaruhi oleh pasang surut. Perubahan kadar salinitas di perairan estuaria sangat mempengaruhi kehidupan organisme yang hidup di perairan tersebut. Tentunya ini membawa dampak terhadap kemampuan organisme tersebut untuk mampu mentolerir fluktuasi salinitas yang cukup tinggi (Andrews, 1987).

Pantai Morosari tersusun atas daerah pantai terbuka yang merupakan muara dari Sungai Morosari, daerah pertambakan yang terletak di antara Sungai Morosari dan Sungai Pandansari serta muara dari Sungai Pandansari. Muara dari Sungai Pandansari tersusun atas wilayah - wilayah yang banyak ditumbuhi tanaman mangrove jenis Rhizophora sp. dan Avicennia sp. Pada ketiga daerah tersebut saat ini sering mengalami genangan akibat air pasang yang tinggi atau disebut rob. Kondisi tersebut menyebabkan beberapa daerah akan selalu tergenang pada saat terjadinya pasang.

\section{Berdasarkan} pengamatan pendahuluan pada ketiga jenis wilayah tersebut banyak dijumpai ikan beloso (Oxyurichthys microlepis) dari family gobiidae, yang tertangkap dengan menggunakan peralatan jaring lift net. Ikan beloso (Oxyurichthys microlepis) merupakan ikan demersal dan bersifat amphidromous, hidup di air payau (daerah pasang surut), biasanya di ekosistem mangrove sekitar wilayah estuaria(FroesedanPauly, 2000). Kondisi tersebut memberikan gambaran bahwa ikan beloso memanfaatkan wilayah perairan Morosari sebagai bagian dari siklus hidupnya, baik untuk tempat mencari makan, perlindungan atau menghindar dari predator. Dengan demikian pemanfaatan kondisi perairan di Morosari oleh ikan beloso dan membutuhkan pengamatan lebih lanjut khususnya terhadap populasi biologinya. Informasi yang berhubungan dengan pertumbuhan populasi ikan dapat memberikan informasi tentang produksi suatu jenis ikan (Effendie, 2002).

Penelitian ini bertujuan untuk mengetahui populasi ikan beloso (Oxyurichthys microlepis) berdasarkan pertumbuhan, hubungan panjang-berat, faktor kondisi dan kebiasaan makan yang terdapat di Perairan Morosari Kecamatan Sayung Kabupaten Demak.

\section{METODE}

\section{Koleksi sampel}

Bahan materi yang digunakan dalam penelitian ini adalah ikan beloso (Oxyurichthys microlepis), yang diukur panjang dan beratnya serta diambil lambungnya. Pada saat bersamaan dilakukan pengamatan terhadap kecerahan, kedalaman, salinitas, suhu, $\mathrm{pH}$, dan kandungan oksigen terlarut (DO) di Perairan Morosari sebagai parameter kualitas perairan. 
Metode pengumpulan sampel yang digunakan dalam penelitian ini adalah dengan metode sample survey method yaitu metode pengumpulan data dengan cara mencatat sebagian kecil populasi tetapi hasilnya diharapkan dapat menggambarkan sifat populasi (Suwignyo,1976). Dalam penentuan stasiun, penelitian ini menggunakan metoda purposive sampling(Hadi, 1979). Stasiun pengambilan sampel dipilih 3 stasiun yaitu di Muara Morosari, pertambakan dan Muara Pandansari.

Ikan beloso ditangkap dengan menggunakan alat tangkap lift net setiap dua minggu sekali pada bulan Mei-Juni. Ikan beloso hasil tangkapan diukur panjang standar, panjang total dan berat. Data yang diperoleh dianalisis dengan menggunakan model pertumbuhan Von Bertalanffy, hubungan panjang-berat, faktor kondisi dan kebiasaan makan ikan.

\section{Analisa Data}

- Pertumbuhan panjang ikan dapat diduga dengan menggunakan persamaan Von Bertalanffy (Sparredan Venema, 1999), sebagai berikut:

$$
\mathrm{Lt}=\mathrm{L} \infty\left(1-\mathrm{e}^{-\mathrm{K}(\mathrm{t}-\mathrm{t} 0)}\right) \quad \text { Pers }(1)
$$

dimana : Lt : Ukuran panjang ikan pada saat umur $\mathrm{t}(\mathrm{cm}), \mathrm{L} \infty$ : Panjang maksimum ikan yang dapat dicapai $(\mathrm{cm})$, e : Dasar logaritma natural, $\mathrm{t}$ : Umur ikan, $\mathrm{t}_{0}$ : Parameter kondisi awal, $\mathrm{K}$ : Koefisien Pertumbuhan

- Pertumbuhan berat ikan dapat diduga dengan menggunakan persamaan Von
Bertalanffy (Sparredan Venema, 1999), sebagai berikut:

$$
\mathrm{Wt}=\mathrm{W} \infty\left(1-\exp ^{-\mathrm{K}(\mathrm{t}-\mathrm{t} 0)}\right)^{3} \quad \text { Pers (2) }
$$
dimana : Wt : Ukuran berat ikan pada saat umur t (gram), Wo: Berat maksimum ikan yang dapat dicapai (gram), e : Dasar logaritma natural, $\mathrm{t}$ : Umur ikan, $\mathrm{t}_{0}$ : Parameter kondisi awal, $\mathrm{K}$ : Koefisien Pertumbuhan

- Pada hubungan panjang-berat ikan, berat ikan dapat dianggap suatu fungsi dari panjangnya (Effendie, 2002). Kegunaan dari perhitungan panjang-berat ini, yaitu dapat untuk menduga berat ikan berdasarkan panjangnya. Adapun bentuk umum dari persamaan panjang-berat ikan menurut (Johnson dan Ndimele, 2010)yaitu :

$$
\mathrm{W}=\mathrm{a} \mathrm{L}^{\mathrm{b}} \quad \text { Pers (3) }
$$

dimana :W : berat ikan, $\mathrm{L}$ : panjang ikan, a : konstanta, $\mathrm{b}$ : eksponen

- Pada sistem metrik yang biasa digunakan di Indonesia kita dapat menentukan suatu keadaan tipe tubuh ikan yang bersifat allometrik pada perairan Indonesia dengan menggunakan rumus sebagai berikut :

$$
\mathrm{K}_{(\mathrm{Ti})}=\frac{10^{5} \mathrm{~W}}{\mathrm{~L}^{3}} \operatorname{Pers}(4)
$$

dimana : $\mathrm{K}_{(\mathrm{Ti})}$ :panjang total ikan, $\mathrm{W}$ : berat rata-rata ikan yang sebenarnya (gram) yang terdapat dalam satu kelas, L :panjang rata-rata ikan dalam milimeter yang dalam kelas tersebut (Lagler, 1961).

- Pendugaan isi lambung dilakukan dengan mengadakan pengamatan pada isi 
lambung. Lambung dari ikan beloso dibuka kemudian dilihat komposisinya.

\section{HASIL DAN PEMBAHASAN}

Hasil pengukuran panjang standar, panjang total serta berat terhadap ikan beloso (Oxyurichthys microlepis) yang diperoleh pada Perairan Morosari sejumlah 138 ekor, menunjukan kisaran panjang 14 23,9 cm, sedangkan kisaran beratnya 5 -
69,99 gram. Hasil tersebut adalah hasil keseluruhan sampling yang dilakukan selama 5 kali selama 2 bulan dengan interval waktu tiap 2 minggu sekali. Hasil selengkapnya mengenai frekuensi sebaran pengukuran ikan beloso (O. microlepis) berdasarkan panjang dan berat tubuhnya mulai dari bulan Mei-Juni disajikan pada tabel 1 dan tabel 2 .

Tabel1.Sebaran Frekuensi Panjang Total Ikan Beloso (O. microlepis)Hasil Sampling BulanMei - Juni

\begin{tabular}{ccccccc}
\hline $\begin{array}{c}\text { Interval } \\
\text { Panjang (cm) }\end{array}$ & $\begin{array}{c}\text { Nilai } \\
\text { Tengah (cm) }\end{array}$ & $\begin{array}{c}\text { 2 Mei } \\
\text { (ekor) }\end{array}$ & $\begin{array}{c}\text { 15 Mei } \\
\text { (ekor) }\end{array}$ & $\begin{array}{c}\text { 29 Mei } \\
\text { (ekor) }\end{array}$ & $\begin{array}{c}\text { 14 Juni } \\
\text { (ekor) }\end{array}$ & $\begin{array}{c}\text { 26 Juni } \\
\text { (ekor) }\end{array}$ \\
\hline $14-14,9$ & 14,45 & 2 & 0 & 0 & 0 & 1 \\
$15-15,9$ & 15,45 & 2 & 0 & 1 & 1 & 0 \\
$16-16,9$ & 16,45 & 4 & 3 & 4 & 3 & 1 \\
$17-17,9$ & 17,45 & 13 & 4 & 7 & 7 & 1 \\
$18-18,9$ & 18,45 & 4 & 7 & 7 & 5 & 1 \\
$19-19,9$ & 19,45 & 3 & 8 & 12 & 4 & 3 \\
$20-20,9$ & 20,45 & 4 & 4 & 4 & 4 & 0 \\
$21-21,9$ & 21,45 & 3 & 2 & 1 & 1 & 2 \\
$22-22,9$ & 22,45 & 0 & 2 & 0 & 0 & 0 \\
$23-23,9$ & 23,45 & 0 & 1 & 0 & 0 & 2 \\
\hline TOTAL (EKOR) & & 35 & 31 & 36 & 25 & 11 \\
\hline
\end{tabular}

Tabel2.Sebaran Frekuensi Berat Total Ikan Beloso (O.microlepis) Hasil Sampling Bulan Mei - Juni

\begin{tabular}{ccccccc}
\hline $\begin{array}{c}\text { Interval Berat } \\
\text { (gr) }\end{array}$ & $\begin{array}{c}\text { Nilai } \\
\text { Tengah (gr) }\end{array}$ & $\begin{array}{c}\mathbf{2 ~ M e i} \\
\text { (ekor) }\end{array}$ & $\begin{array}{c}\text { 15 Mei } \\
\text { (ekor) }\end{array}$ & $\begin{array}{c}\text { 29 Mei } \\
\text { (ekor) }\end{array}$ & $\begin{array}{c}\text { 14 Juni } \\
\text { (ekor) }\end{array}$ & $\begin{array}{c}\text { 26 Juni } \\
\text { (ekor) }\end{array}$ \\
\hline $5-9,99$ & 7,49 & 2 & 0 & 0 & 0 & 0 \\
$10-14,99$ & 12,49 & 2 & 0 & 1 & 0 & 0 \\
$15-19,99$ & 17,49 & 7 & 1 & 4 & 4 & 1 \\
$20-24,99$ & 22,49 & 12 & 14 & 15 & 13 & 2 \\
$25-29,99$ & 27,49 & 7 & 11 & 15 & 7 & 3 \\
$30-34,99$ & 32,49 & 2 & 3 & 1 & 1 & 2 \\
$35-39,99$ & 37,49 & 2 & 1 & 0 & 0 & 0 \\
$40-44,99$ & 42,49 & 1 & 1 & 0 & 0 & 2 \\
$45-49,99$ & 47,49 & 0 & 0 & 0 & 0 & 0 \\
$50-54,99$ & 52,49 & 0 & 0 & 0 & 0 & 0 \\
$55-59,99$ & 57,49 & 0 & 0 & 0 & 0 & 0 \\
$60-64,99$ & 62,49 & 0 & 0 & 0 & 0 & 0 \\
$65-69,99$ & 67,49 & 0 & 0 & 0 & 0 & 1 \\
\hline T0TAL (EKOR) & & 35 & 31 & 36 & 25 & 11 \\
\hline
\end{tabular}


Pertumbuhan Ikan Berdasarkan Panjang dan Berat

\section{Pertumbuhan berdasarkan panjang}

Hasil analisis terhadap sebaran frekuensi panjang ikan beloso (O. microlepis) pada sampling bulan Mei-Juni menunjukkan nilai intersep (a) sebesar -0,236 dan nilai slope (b) adalah 0,0175 (Tabel 3, Gambar 1). Berdasarkan persamaan tersebut dihasilkan model pertumbuhan Von Bertallanfy $\mathrm{L}(\mathrm{t})=$ 13,49 ( 1 - $\left.\exp ^{0,0175(t-1,9053)}\right)$.

Tabel-3. Panjang Ikan Beloso (O. microlepis) Berdasarkan Class Cohort

\begin{tabular}{lllllll}
\hline No & $\mathbf{\Delta t}$ & $\mathbf{L 1}(\mathbf{c m})$ & $\mathbf{L 2}(\mathbf{c m})$ & $\mathbf{\Delta L}$ & $\mathbf{L t}(\mathbf{c m})$ & $\mathbf{( \Delta \mathbf { L } / \boldsymbol { \Delta t } )}$ \\
\hline Incr 1 & 14 & 16,45 & 17,4 & 0,95 & 16,925 & 0,06786 \\
Incr 2 & 14 & 17,4 & 18,45 & 1,05 & 17,925 & 0,075 \\
Incr 3 & 14 & 18,45 & 19,6 & 1,15 & 19,025 & 0,08214 \\
Incr 4 & 14 & 19,6 & 21,45 & 1,85 & 20,525 & 0,13214 \\
\hline
\end{tabular}

Berdasarkan hasil perhitungan analisis data, pertumbuhan ikan beloso $(O$. microlepis) di Perairan Morosari mempunyai nilai Lo sebesar13,49 cm. Pertumbuhan ikan ditentukan oleh faktor makanan (Effendie, 2002).Pertumbuhan biota dipengaruhi oleh kebiasaan makan ikan, sedangkan kebiasaan makan ikan dipengaruhi oleh faktor lingkungannya (Lagler et.al.,1962). Pertumbuhan panjang ikan beloso $(O$. microlepis) di Perairan Morosari dengan Lo sebesar13,49 cm lebih kecil dari pada pertumbuhan ikan family gobiidae yang lain yaitu ikan Gobius vittatus yang didapatkan dari Laut Adriatic Utara yang memiliki L $\infty$ sebesar 50,13 cm (Kovacic,2006). Hal ini berarti bahwa waktu yang dibutuhkan untuk bertambah panjang oleh ikan beloso $(O$. microlepis) yang ada di Perairan Morosari lebih lama dari pada ikan
G. vittatus di Laut Adriatic. Pertumbuhan ikan beloso (O. microlepis) berkaitan erat dengan kondisi lingkungannya. Selanjutnya ditambahkan, L $\infty$ yang dicapai oleh ikan beloso di Perairan Morosari menunjukkan bahwa ikan tersebut memanfaatkan daerahdaerah perairan tersebut sebagai habitat untuk periode waktu yang cukup lama atau hampir seluruh siklus hidupnya. Dengan demikian, panjang yang dicapai oleh ikan beloso tersebut terkait erat dengan daya dukung lingkungan khususnya kualitas perairan dan jumlah maupun jenis makanan.

\section{Pertumbuhan berdasarkan berat}

Hasil analisis terhadap sebaran frekuensi berat ikan beloso (O.microlepis) pada sampling bulan Mei-Juni 2010 menunjukkan nilai intersep (a) sebesar 0,385 dan nilai slope (b) adalah 0,003 (Tabel 4, Gambar 2). 

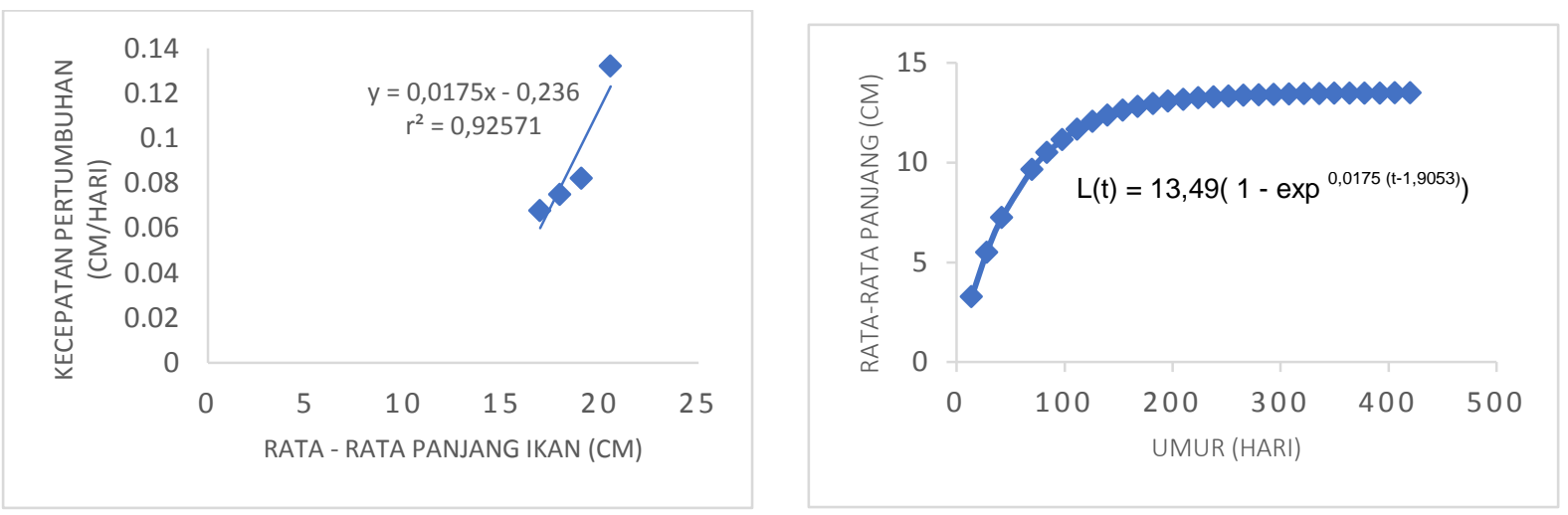

Gambar-1. Persamaan Panjang Ikan Beloso (O. microlepis) Berdasarkan Class Cohort (atas); Kurva Pertumbuhan Berdasarkan Panjang Ikan Beloso (O. microlepis) (bawah) (Olah Data Penelitian, 2019)

Berdasarkan persamaan tersebut dihasilkan model pertumbuhan Von Bertallanfy $128,33\left(1-\exp ^{-0,02(t-2,4312)}\right)^{3}$.

Tabel-4. Berat Ikan Beloso (O. microlepis) Berdasarkan Class Cohort

\begin{tabular}{|c|c|c|c|c|c|c|}
\hline No & $\Delta t$ & $\begin{array}{l}\text { W1 } \\
\text { (gr) }\end{array}$ & $\begin{array}{l}\text { W2 } \\
\text { (gr) }\end{array}$ & $\Delta \mathbf{W}$ & $\begin{array}{l}\text { Wt } \\
\text { (gr) }\end{array}$ & $(\Delta \mathrm{W} / \Delta \mathrm{t})$ \\
\hline Incr & & & & & & 0,713571 \\
\hline 1 & 14 & 15 & 24,99 & 9,99 & 19,995 & 4 \\
\hline Incr & & & & & & 0,143571 \\
\hline 2 & 14 & 24,9 & 27 & 2,01 & 25,995 & 4 \\
\hline Incr & & & & & & 0,428571 \\
\hline 3 & 14 & 27 & 33 & 6 & 30 & 4 \\
\hline Incr & & & & & & 0,678571 \\
\hline 4 & 14 & 33 & 42,5 & 9,5 & 37,75 & 4 \\
\hline
\end{tabular}

Hasil analisis pertumbuhan berdasarkan berat menunjukkan model pertumbuhan ikan beloso (O. microlepis) dengan nilai $\mathrm{W} \infty$ sebesar 128,33 gram. Pencapaian berat tersebut terkait dengan kandungan nutrisi dari makanan yang tersedia di daerah muara Pandansari perairan Morosari. Daerah muara Pandan sari terdapat banyak tanaman mangrove dengan jenis Avicennia sp. Dan Rhizophora sp. Keberadaan mangrove ini sangat mempengaruhi tingginya produktivitas primer di daerah tersebut. 

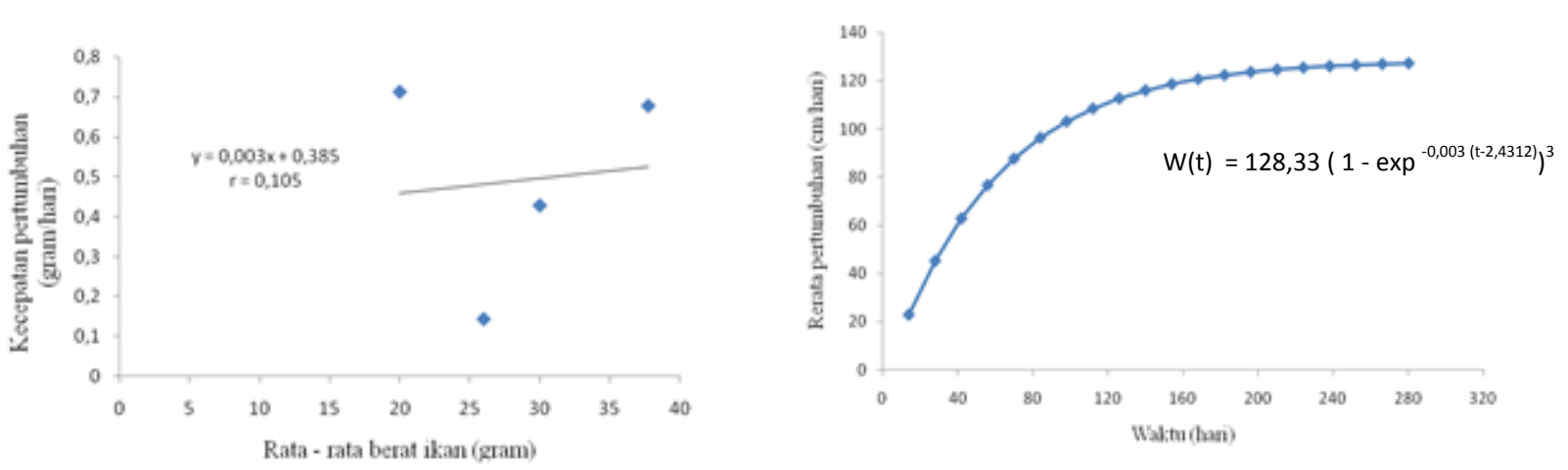

Gambar-2. Persamaan Berat Ikan Beloso (O. microlepis) Berdasarkan Class Cohort (atas); Pertumbuhan Berdasarkan Berat Ikan Beloso (O. microlepis) (bawah) (Olah Data Penelitian, 2019)

Habitat mangrove merupakan tempat yang baik untuk berlindung, pemijahan dan mencari makanan. Hal ini juga dibuktikan dengan hasil analisis isi lambung, yang menunjukkan bahwa jenis-jenis makanan yang dimangsa oleh ikan beloso merupakan makanan yang banyak dijumpai di daerah muara/perairan dan daerah mangrove. Hal ini sesuai dengan Dahuri (2003), yang menyatakan bahwa ikan yang berada pada daerah mangrove merupakan habitat yang baik untuk mencari makan. Hutan mangrove berperan penting dalam mendukung populasi ikan karena mereka menyediakan bahan organik dan detritus sebagai sumber makanan (Khaironizam dan Norma-Rashid, 2002). Selain itu, untuk ikan beloso yang ada di Perairan Morosari, ketersediaan makanan merupakan faktor terpenting untuk laju pertumbuhannya.

Hubungan Panjang-Berat Ikan Beloso (O. microlepis)
Hasil analisis data panjang dan berat ikan beloso (O. microlepis) di Perairan Morosari menunjukkan persamaan $\mathrm{y}=$ 1,451x - 0,464 ( $\mathrm{r}=0,514433$ ) (Gambar 3), dan menghasilkan hubungan panjang berat $\mathrm{W}=$ $0,464 \mathrm{~L}^{1,451}$.

Hubungan panjang-berat ikan beloso (O. microlepis) didapatkan persamaan linier hubungan panjang dengan berat yaitu $\mathrm{y}=1,451 \mathrm{x}-0,464$ di Perairan Morosari, dimananilai $b$ adalah 1,451. Apabila $b<3$ maka pertambahan panjang lebih cepat dari beratnya disebut dengan pertumbuhan allometrik negatif. Nilai b sebesar 1,451 memperlihatkan bahwa ikan beloso mempunyai kegemukan yang kurang tampak pada saat dilaksanakannya sampling. Ditambahkan lagi bahwa harga b yang kurang dari 3 menunjukkan keadaan ikan yang kurus yaitu pertambahan panjangnya lebih cepat dari pertambahan beratnya (Effendie, 2002). Pertumbuhan panjang lebih cepat yang dialami Ikan Beloso terkait dengan kandungan asupan makanan. 


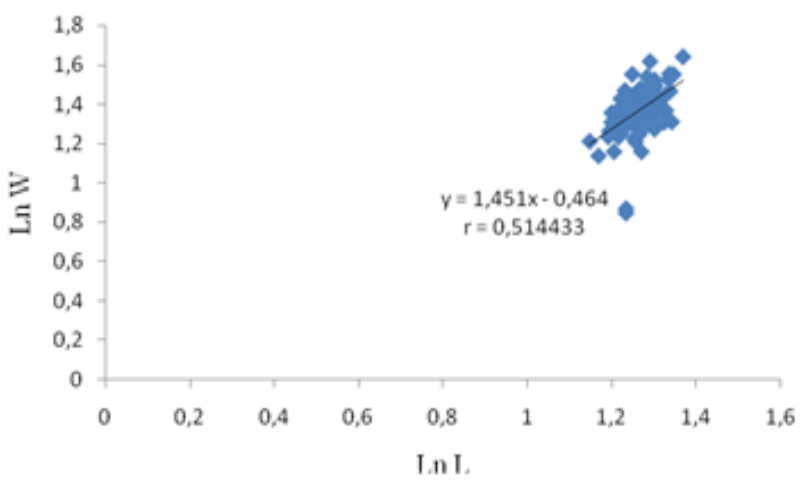

Gambar-3.Regresi Panjang Total Dengan Berat TotalIkan Beloso (O. microlepis)(Olah Data Penelitian, 2019)

Makanan dari Ikan Beloso banyak mengandung protein dan karbohidrat. Namun demikian, nilai panjang-berat ikan beloso tidak bersifat permanen. Hal ini sesuai dengan Sulistiyonoet.al. (2001), yang menyatakan bahwa hubungan panjang-berat menunjukkan pertumbuhan yang bersifat relatif artinya dapat berubah menurut waktu. Apabila terjadi perubahan terhadap lingkungan dan ketersediaan makanan diperkirakan nilai ini juga akan berubah.

\section{Faktor Kondisi Ikan Beloso (O. microlepis)}

Faktor kondisi ikan beloso $(O$. microlepis) menunjukkan kisaran nilai di antara0,0965 - 0,3661 (Tabel 5, Gambar 4).

Faktor kondisi ikan beloso $(O$. microlepis) berkisar antara 0,0965 - 0,3661.
Menurut Lagler (1961), nilai K akan dipengaruhi oleh ikan itu sendiri.Berdasarkan pada gambar 16, kurva faktor kondisi, ikan beloso (O. microlepis) mempunyai tubuh yang kurang pipih. Lagler (1961) menyatakan bahwa ikan yang badannya kurang pipih mempunyai nilai $\mathrm{K}$ berkisar antara 1-3. Berdasarkan kisaran panjangnya, ikan beloso (O. microlepis) merupakan ikan yang berukuran kecil. Ukuran kecil ini akan mempengaruhi faktor kondisi ketika ikan bertambah dewasa. Menurut (Effendie, 2002), faktor kondisi berfluktuasi dengan ukuran ikan, ikan yang berukuran kecil mempunyai kondisi yang relatif tinggi kemudian menurun ketika ikan bertambah besar.

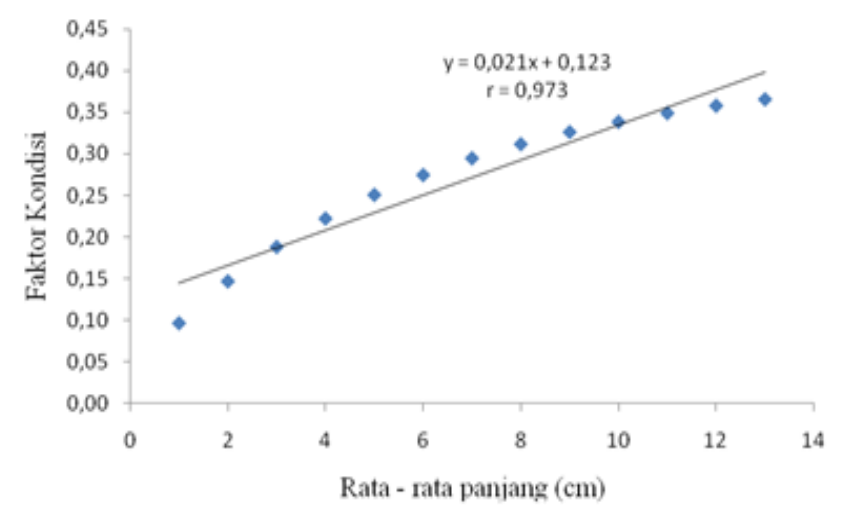

Gambar-4. Kurva Faktor Kondisi Berdasarkan Panjang Ikan Beloso $(O$. microlepis) di Perairan Morosari Selama Periode Bulan Mei - Juni 
Tabel-5. Faktor Kondisi Rata-Rata Ikan Beloso (O. microlepis)Berdasarkan Selang Panjang dan Berat di Muara Sungai Morosari

\begin{tabular}{lllllll}
\hline $\begin{array}{l}\text { Interval } \\
\text { Panjang (cm) }\end{array}$ & $\begin{array}{l}\text { Interval } \\
\text { Kelas Berat } \\
\text { (Gram) }\end{array}$ & $\begin{array}{l}\text { Rata-rata } \\
\text { Panjang } \\
\text { (cm) }\end{array}$ & $\begin{array}{l}\text { Berat } \\
\text { (gr) }\end{array}$ & Kisaran & $\begin{array}{l}\text { Faktor Kondisi } \\
\text { rata-rata }\end{array}$ \\
\hline $14-14,9$ & $5-9,99$ & 14,45 & 7,49 & $0,0965-0,1241$ & 0,0965 & \\
$15-15,9$ & $10-14,99$ & 15,45 & 12,49 & $0,1469-0,1695$ & 0,1469 & \\
$16-16,9$ & $15-19,99$ & 16,45 & 17,49 & $0,1883-0,2070$ & 0,1883 & \\
$17-17,9$ & $20-24,99$ & 17,45 & 22,49 & $0,2226-0,2381$ & 0,2226 & \\
$18-18,9$ & $25-29,99$ & 18,45 & 27,49 & $0,2511-0,2641$ & 0,2511 & \\
$19-19,9$ & $30-34,99$ & 19,45 & 32,49 & $0,2750-0,2859$ & 0,2750 & \\
$20-20,9$ & $35-39,99$ & 20,45 & 37,49 & $0,2952-0,3044$ & 0,2952 & \\
$21-21,9$ & $40-44,99$ & 21,45 & 42,49 & $0,3122-0,3201$ & 0,3122 & \\
$22-22,9$ & $45-49,99$ & 22,45 & 47,49 & $0,3267-0,3334$ & 0,3267 & \\
$23-23,9$ & $50-54,99$ & 23,45 & 52,49 & $0,3390-0,3447$ & 0,3390 & \\
$24-24,9$ & $55-59,99$ & 24,45 & 57,49 & $0,3495-0,3544$ & 0,3495 & \\
$25-25,9$ & $60-64,99$ & 25,45 & 62,49 & $0,3585-0,3626$ & 0,3585 & \\
$26-26,9$ & $65-69,99$ & 26,45 & 67,49 & $0,3661-0,1853$ & 0,3661 & turut \\
\hline
\end{tabular}

\section{Kualitas Perairan Morosari}

Berdasarkan pengukuran kualitas perairan di Morosari, data menunjukkan bahwa Perairan Morosari mempunyai nilai suhu sebesar28,3 - 32,5 ${ }^{\circ} \mathrm{C}$, salinitas 21,7 $28,3 \%$, kecerahan 32,67 - 64,33 cm, pH 7 - 8 dan DO 4,32 - 8,8 mg/l. Suhu Perairan Morosari sebesar28,3 $-32,5{ }^{\circ} \mathrm{C}$ merupakan suhu yang sesuai untuk ikan beloso bertahan hidup karena besar suhu tidak mencapai suhu kritis bagi kehidupan organisme air laut. Kinne (1972) menyatakan bahwa suhu air yang berkisar antara $35-40^{\circ} \mathrm{C}$ merupakan suhu kritis bagi kehidupan organisme yang dapat menyebabkan kematian. Selain itu suhu ikut berperan penting dalam ketersediaan makanan dan terkait dengan proses fotosintesis. Hal ini sesuai dengan Romimohtarto dan Juwana (2007) bahwa suhu mendorong permukaan massa air yang menyediakan zat hara serta mempengaruhi daya larut gas $\mathrm{CO}_{2}$ dan $\mathrm{O}_{2}$ yang diperlukan untuk fotosintesis. mempengaruhi kehidupan biota laut. Salinitas Perairan Morosari sebesar 21,7 28,3 \%o. Salinitas ini cocok untuk kehidupan ikan beloso karena ikan beloso termasuk ikan euryhaline yang dapat tumbuh pada batas maksimum 35 ppt. Ikan yang tinggal di muara kebanyakan adalah ikan euryhaline. Lebih lanjut lagi, ikan beloso mempertahankan konsentrasi garam mereka pada tingkat yang lebih tinggi atau lebih rendah dari air laut. Menurut Andrews (1987) organisme yang hidup di daerah dengan perubahan salinitas yang ekstrim, seperti di daerah pasang surut, merespon dalam tiga cara pertama. Beberapa pindah ke area salinitas optimal. Atau mereka dapat melindungi diri di bawah batu atau di kolam pasang surut. Lainnya mengurangi kontak tubuh dengan air sekitarnya. Mereka melakukan ini dengan mengeluarkan lendir atau dengan menarik diri ke dalam liang. Hal ini biasanya menyebabkan metabolisme tubuh ikan tersebut menurun. 
Kecerahan di Perairan Morosari sebesar32,67 - 64,33 cm menunjukkan bahwa proses fotosintesis fitoplankton dapat terjadi. Romimohtarto dan Juwana (2007) menyatakan bahwa proses fotosintesis akan terjadi sangat efektif pada daerah euphotic zone yaitu zona dengan kedalaman antara 0100 meter.

Nilai pH di Perairan Morosari adalah 7 8. Mintardjo et.al. (1985) mengatakan bahwa titik kematian ikan terjadi pada $\mathrm{pH} 4,00$ untuk asam dan 11,00 untuk basa.Oksigen terlarut yang ada di Perairan Morosari antara 4,32 - 8,8 mg/l.Oksigen terlarut sangat diperlukan untuk pernapasan dan metabolisme ikan dan berkembang biak [15].

\section{Pendugaan Isi Lambung}

Berdasarkan hasil analisa lambung, ikan beloso (O. microlepis) adalah pemangsa fitoplankton, zooplankton dan detritus. Hal ini menunjukan bahwa ikan beloso $(O$. microlepis) termasuk dalam jenis omnivora. Jenis fitoplankton dan zooplankton yang dimakan oleh ikan beloso (O. microlepis) berbeda-beda dengan prosentase yang berbeda pula. Menurut (Effendie, 2002) perbedaan jumlah organisme makanan yang dimakan ikan terjadi karena perbedaan sebaran organisme tersebut pada masingmasing wilayah. Ditambahkan lagi bahwa faktor yang mempengaruhi kesukaan organisme perairan terhadap makanannya antara lain adalah faktor penyebaran organisme makanan, faktor ketersediaan makanan, faktor pilihan dari ikan itu sendiri dan faktor lingkungan perairan.

\section{KESIMPULAN}

Kesimpulan dari penelitian ini bahwa pertumbuhan ikan beloso (O. microlepis) di Perairan Morosari memiliki nilai L $\infty$ sebesar $13,49 \mathrm{~cm}$ dengan persamaan $\mathrm{L}(\mathrm{t})=13,49$ ( 1 - exp 0,0175 (t-1,9053)) untuk panjang, sedangkan berdasarkan berat diperoleh W $\infty$ sebesar 5,8 gram dengan persamaan $\mathrm{W}(\mathrm{t})=128,33(1-$ $\exp -0,02(t-1,9459))^{3}$. Hubungan panjang-berat ikan beloso di Perairan Morosari menghasilkan nilai b sebesar 1,451 . Nilai ini menunjukkan bahwa pertumbuhan ikan beloso bersifat allometrik negatif, dimana pertambahan panjang lebih cepat dari beratnya. Berdasarkan hasil perhitungan data faktor kondisi ikan beloso di Perairan Morosari menunjukkan kisaran faktor kondisi sebesar 0,0965 - 0,3661, dimana energi makanan lebih diutamakan pertambahan panjang. Ikan beloso merupakan ikan omnivora yang mengkonsumsi fitoplankton, zooplankton, dan detritus sebagai makanan yang dijumpai di daerah estuaria dan daerah Muara Pandansari yang banyak ditumbuhi oleh tanaman mangrove.

\section{DAFTAR PUSTAKA}

Andrews, W. A., 1987. Investigating Aquatic Ecosystem. Canada: Prentice-Hall Canada Inc..

Dahuri, R., 2003. Keanekaragaman Hayati Laut Aset Pembangunan Berkelanjutan 
Indonesia. Jakarta: Gramedia Pustaka Umum.

Effendie, M. I., 2002. Biologi Perikanan. Yogyakarta: Yayasan Pustaka Nusatama.

Froese, R. a. D. P. E., 2000. FishBase 2000: Concept, Design and Data Sources. Los Banos, Laguna, Philippines: ICLARM.

Hadi, S., 1979. Metodologi Research: Penulis Paper, Skripsi, Thesis dan Disertasi. Yogyakarta: Yayasan Penerbit Fakultas Psikologi.

Johnson, C. A. K. a. P. E. N., 2010. LengthWeight Relationships and Condition Factors of Twenty-One Fish Species in Ologe Lagoon, Lagos, Nigeria. Asian Journal of Agricultural Sciences, vol. 2, no. 4, pp. 174-179.

Khaironizam, M. a. Y. N.-R., 2002. Lengthweight Relationship of Mudskippers (Gobiidae: Oxudercinae) in the Coastal Areas of Selangor, Malaysia. Naga World Fish Center Quarterly, vol. 25, no. 3\&4, pp. 20-22.

Kinne, O., 1972. Marine Ecology: Environmental Factors. New York: Wiley Inter Science.

Kovacic, M., 2006. Age Structure, Growth and Mortality of The Striped Goby, Gobius vittatus (Gobiidae) in The Northern Adriatic Sea. Scientia Marina, vol. 70, no. 4, pp. 635-641.

Lagler K. F., B. J. E. a. M. R. R., 1962. Ichthyology. New York: John Willey \& Sons. Inc..

Lagler, K. F., 1961. Freshwater Fishery Biology. Second Edition. Dubuque, Lowa: WM. C. Brown Co. .

Mintardjo, K. A. S. d. H. U., 1985. Persyaratan Tanah dan Air dalam Pedoman
Budidaya Tambak. Jakarta: Dirjend Perikanan Deptan.

Romimohtarto, K. d. S. J., 2007. Biologi Laut. Jakarta: Djambatan.

Sparre, P. a. S. V., 1999. Introduksi Pengkajian Stok Ikan Tropis. Jakarta: Pusat Penelitian dan Pengembangan LIPI.

Sulistiono, M. A. d. K. A. A., 2001. Pertumbuhan Ikan Belanak (Mugil dussumierf) di Perairan Ujung Pangkah, Jawa Timur. Jurnal Ikhtiologi Indonesia, vol. 1, no. 2, pp. 39-47.

Suwignyo, F., 1976. Metode dan Teknik Penelitian dalam Bidang Biologi Perairan. Bogor: Fakultas Perikanan IPB. 